Прегледни

рад
Година (XXVI) XIII, vol=42

Бр. 4 / 2014.

стр. 141-160.

\title{
Звонко Брнам*
}

Факултета за банкарство, осигурање и финансије,Београд

Божо Драшковић ${ }^{* *}$

Институт економских наука, Београд

\section{ГРАЂАНИ И БУЏЕТСКИ ПРОЦЕС НА ЛОКАЛНОМ НИВОУ ${ }^{* * *}$}

\begin{abstract}
Сажетак
Учешће грађана (у ширем смислу јавности уопите) је веома важан аспект функционисања друштвено-економских система у земљама у транзицији. Ово питана значајно је како са становишта развоја демократије, тако и ефикасности и ефективности економског система, посебно оног његовог дела који се односи на јавни сегмент система (јавни или државни сектор у најширем смислу). Учешће грађана је процес којим се проблеми, потребе и жеље грађана уграђују y прочес доношена одлука локалне самоуправе. Он подразумева двосмерну комуникацију између грађана и локалних власти чији је заједнички циљ доношењье квалитетнијих одлука које имају јавну подршку. На локалном нивоу учешће јавности може утицати на одлуке у различитим областима: у области доношења локалних јавних политика и правних аката, приликом припреме и усвајања локалних развојних планова $и$ програма, као и код дефинисања и реализације конкретних пројеката на локалном нивоу.
\end{abstract}

Редовни професор Београдске банкарске академије, Научни сарадник Института економских наука.

** Научни сарадник.

*** Овај рад је део истраживачког пројекта под шифром 179015 (Изазови и перспективе структурних промена у Србији: Стратешки правци економског развоја и усклађивање са захтевима ЕУ), финансираног од стране Министарства за науку и технолошки развој Републике Србије. 
У раду је посебан акиенат стављен на питање укључивана грађана у буиетски процес на локалном нивоу у јединицама локалне самоуправе (градовима и опитинама) у Србији. У зависности од облика и степена утииаја грађана на прочесе доношење одлука у јавном сектору, можемо разликовати више нивоа юихове партиципације. Они се крећу од основног нивоа који подразумева информисање грађана о питањима јавне управе (ова форма по природи ствари уједно има и карактер едукације); иде даље преко прикупьана информација и упознавања са мишьенима и ставовима грађана; затим преко комуникације власти са грађанима која подразумева повратне везе (непосредни дијалог), до партнерског односа у коме грађани непосредно партищипирају у прочесу доношења одлука.

Кључне речи: Локална самоуправа, Учешће грађана, Буцетски процес, Транспарентност јавних функиија, Правни оквир партищипаџије грађана.

Y чешће грађана, а посебно сегмент који се односи на локални ниво власти, представља важан облик непосредне демократије који се манифестује у свакодневном животу локалних заједница. Овакав концепт демократије се може применити како у земљама развијене демократије, тако и у мање развијеним и земљама у транзицији Слободни избори свакако представљају основу демократије. Наведени концепт подразумева међутим да је демократија више од слободних избора. „Владавина народа, од народа и у корист народа“"1), претпоставља партнерство између грађана и њихових изабраних представника које се мора пренети на све званичнике и институције власти. У демократским земљама широм света, овакав однос грађана и њихових изабраних представника у власти, укључујући и оне на локалном нивоу, обезбеђује одговорни и транспарентни рад званичника и стварање могућности да грађани учествују у раду локалне самоуправе, чак и у њеним свакодневним активностима. На грађанима је да искористе ову могућност, док званичници и на локалном и на вишим нивоима власти, треба да их охрабре да учествују у свакодневним активностима управе. Овај процес је данас у Србији већ постао неповратан, мада треба имати у виду да је потребно још много тога урадити да би потенцијали демократије у потпуности дошли до изражаја у свакодневном животу локалних заједница.

1) Сентенца изречена још средином 19-тог века којом је Абрахам Линколн дефинисао суштину демократије. 
Да би се поменуто партнерство између грађана и власти остварило, неопходно је да се информације које су важне за живот у заједници учине грађанима доступним. На пример, грађани треба да буду информисани о начину на који се одвија процес доношења буџета локалне самоуправе, о његовом основном садржају и најважнијим компонентама, као и начину на који ће његова имплементација утицати на њихов и живот целе заједнице.

Истовремено, представници власти приликом доношења одлука којима се уобличава живот заједнице и свих њених појединаца, би морали да буду упознати са мишљењем грађана које представљају. Локалне власти треба да буду упознати са тиме шта грађани мисле о услугама које им локална самоуправа пружа и у ту сврху на располагање им стоји читав арсенал управљачких алатки о којима ће касније бити нешто више речи.

Коначно, грађане је потребно позивати да као добровољни представници учествују у раду различитих радних група, комисија и саветодавних група које се формирају како би помогле локалним властима да успешније испуњавају обавезе. Грађани на овај начин могу бити веома креативни и од велике помоћи у изналажењу решења за различите проблеме, као и у свакодневном раду локалне самоуправе.

На крају, треба свакако имати у виду да ма како учешће грађана било од кључног значаја за демократију, ради се о пракси коју није увек лако остварити. За то је по правилу потребно много политичке воље, упорности и опредељености за сталну едукацију, како грађана, тако и званичника, о њиховим међусобним обавезама и правима током процеса развоја демократије.

\section{1. ДЕФИНИЦИЈА УЧЕШЋА ГРАЋАНА}

Учешће или партиципација грађана подразумева различите активности којима се грађани укључују у процес доношења одлука од јавног значаја и тако непосредно утичу на квалитет свог и живота својих суграђана у оквиру уже или шире друштвене заједнице у којој живе. Оне могу да укључују форме у којима грађани имају активне улоге, нпр. када грађани кроз разне облике удруживања и иницијатива улазе у директну интеракцију са представницима власти. О пасивним облицима партиципације може да се говори када грађани само присуствују састанцима или презента- 
цијама како би се информисали и ближе упознали са конкретним одлукама или програмима. Учешће грађана добија свој пуни облик и ефекат када се грађани окупљају како би се информисали и разговарали о проблемима своје заједнице, да би затим као резултат тога понудили потенцијална решења представницима власти, а затим и узели учешће у имплементацији понуђених решења.

Пракса непосредног учешће грађана у функционисању власти на свим нивоима, а посебно на локалном, представља један од темељних принципа добре демократске праксе и доброг управљања. Она почива на праву грађана да учествују у доношењу одлука и политика које утичу на њихове животе и подразумева заједнички рад свих заинтересованих страна на пројектовању будућности сопствене локалне заједнице. Учешће појединаца у доношењу одлука у њиховој примарној средини нераздвојиво је повезано са правом приступа информацијама и развојним плановима, односно могућношћу учешћа у развоју јединственог плана развоја његове локалне заједнице.

Партиципација подразумева заинтересованост и спремност на сарадњу свих релевантних субјеката, односно органа локалне самоуправе са једне, и грађана, са друге стране. Она подстиче да се међу њима развија и одржава однос међусобног уважавања и разумевања различитих потреба и интереса, а са основним циљем унапређења живота заједнице. Локална самоуправа која је заинтересована за активно укључивање својих грађана спремна је да:

- детаљно и у потпуности информише грађане о свим својим активностима и плановима,

- омогући грађанима да јавно изразе своје мишљење и на тај начин непосредно учествују у доношењу свих значајних одлука,

- охрабри и мотивише грађане да искористе своја права и активно партиципирају у политичком животу,

- инсистира на јавности у процесу доношења процедура укључујући и информације о телима (одборима, комисијама и сл.) који су надлежни за подношење предлога, као и о експертским комисијама који су својим стручним инпутима у процесу, непосредно утицале на доношење коначне одлуке, 
- све донете одлуке јавно образложи (уз недвосмислену аргументацију).

На другој страни, и грађани морају да покажу одређени степен толерантности и политичке културе:

- Пре него што се активно укључи у процес доношења одлука и јавног изражавања мишљења и предлагања решења одређених проблема, сваки појединац би требало да се упозна са правама и обавезама које су му законски задате. Тиме се избегава неодговорно одлучивање о питањима која, директно или индиректно, могу променити животе локалне заједнице.

- У процесу сарадње са локалном самоуправом грађани би требало да имају позитиван приступ у решавању постојећих проблема заједнице.

Партиципација представља, дакле, комбинацију горе наведених елемената: међусобног информисања и комуникације између грађана и локалне самоуправе, спремности грађана да активно учествују у решавању проблема своје заједнице, као и отворености локалних власти да изађу у сусрет потребама и жељама грађана кад год је то могуће.

Имајући горе наведено у виду, учешће грађана би се могло дефинисати као: „...планиран и припремљен процес у коме заинтересовани грађани, организације цивилног друштва и представници власти, заједнички учествују у креирању јавних политика пре него што се политичка одлука донесе. То је сараднички процес решавања проблема с циљем креирања политика с већим степеном легитимитета “(2). Такође ,...учешће јавности подразумева постојање могућности да све заинтересоване стране представе и/ или заступају своје интересе у процесу израде планова, програма,

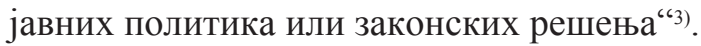

Учешће грађана је процес којим се проблеми, потребе и жеље грађана уграђују у процес доношења одлука локалне самоуправе. Он подразумева двосмерну комуникацију између грађана и локалних власти чији је заједнички циљ доношење квалитетнијих одлука које имају јавну подршку.

2) Public Participation in Europe, An international perspective, European Institute for public participation, June 2009.

3) Standards of Public Participation - Recommendations for Good Practice, Austrian Federal Chancellery, 2008 (http://www.partizipation.at/standards_pp.html) 
На локалном нивоу учешће јавности може утицати на одлуке у различитим сферама: у области доношења јавних политика и правних аката, приликом припреме и усвајања развојних планова и програма, као и код дефинисања конкретних пројеката на локалном нивоу. Будући да је реч о једном од кључних начела одрживог развоја, у основи идеје партиципације јавности налази се низ могућих користи и вредности за различите актере у процесу. У наставку су наведене неке од најважнијих потенцијалних позитивних последица добре праксе учешћа грађана у функционисању локалне самоуправе.

\section{2. ПРАВНИ ОКВИР УЧЕШЋА ГРАЋАНА}

У наредним редовима указаће се најпре на правне основе укључивања грађана у функционисање власти у Европској унији, а затим и на неке од правних елемената на којима се ови процеси одвијају у Републици Србији.

\section{1. ПРАВНИ ОКВИРИ У ЕУ}

Улога и значај учешћа јавности у процесима доношења одлука на локалном нивоу препознати су и признати у многим државама Европе и света. Право грађана да учествују у доношењу одлука о питањима од значаја за живот локалне заједнице могуће је најнепосредније остварити на локалном нивоу, тако да се данас то право сматра саставним делом демократских начела која деле све државе чланице Савета Европе.

Правни и политички документи Савета Европе јасно афирмишу право грађана на непосредно учешће у остваривању локалне самоуправе, почев од Европске повеље о локалној самоуправи (1985), преко касније усвојених препорука и других докумената којима се афирмише учешће грађана на локалном нивоу. Тако је, сходно значају који се у земљама чланицама Савета Европе придаје учешћу грађана у управљању јавним пословима, Савет Европе 2009. године усвојио Допунски протокол уз Европску повељу о локалној самоуправи о праву на учешће у пословима локалних заједница.

Протокол јасно и прецизно дефинише најбоље праксе укључивања грађана у процесе одлучивања и доношења одлука на 
локалном нивоу дајући тиме нову димензију Европској повељи о локалној самоуправи. Овај документ има исту правну природу као и Европска повеља о локалној самоуправи, тако да државе које ратификују овај протокол преузимају обавезу да обезбеде сваком лицу са пребивалиштем на њиховој територији право да учествује у пословима локалне заједнице и да законом предвиде мере којима се олакшава уживање тог права без икакве дискриминације.

Најзначајнији и најопштији документи који формирају правни оквир учешћа грађана у Европи су између осталих следећи:

- Универзална декларација УН о људским правима4)

- Европска повеља о локалној самоуправи5)

- Европска повеља о учешћу младих у јавном животу на локалном и регионалном нивоу6)

- Европска повеља о активном грађанству7)

- Препоруке Комитета министара Савета Европе

У овом смислу може се дакле констатовати да учешће грађана у ЕУ има значајне правне и институционалне основе и да је као пракса постало једно од темељних претпоставки функционисања савремених европских друштава, посебно на локалном нивоу.

\section{2. ПРАВНИ ОКВИР У РЕПУБЛИЦИ СРБИЈИ}

Полазна основа и темељни оквир учешћа грађана, као и свих односа осталих односа у друштву, је Устав Републике Србије. Уставом Републике Србије грађани су одређени као извор суверене власти: „Сувереност потиче од грађана који је врше референдумом, народном иницијативом и преко својих слободно изабраних представника... Ниједан државни орган, политичка организација, група или појединац не може присвојити сувереност од грађана, нити успоставити власт мимо слободно изражене воље грађана“ (Члан 2 Устава). Устав такође установљава да: ”Свако има право да, сам или заједно са другима, упућује петиције и друге

\footnotetext{
4) Универзална декларација о људским правима усвојена од стране Генералне скупштине УН, 10. децембра 1948. године.

5) Европска повеља о локалној самоуправи сачињена у Стразбуру, 15. октобра 1985. године, на енглеском и француском језику. Србија је априла 2003. године приступила Савету Европе, а Европску повељу о локалној самоуправи ратификовала 2007.

6) Савет Европе (Стразбур, 2003.)

7) Савет Европе (Стразбур, 2006.)
} 
предлоге државним органима, организацијама којима су поверена јавна овлашћења ... Због упућивања петиција и предлога нико не може да трпи штетне последице..., „(Члан 56 Устава).

Поред Устава, већи број закона, подзаконских аката и других прописа уређују област партиципације грађана у власти на локалном нивоу. Темељни закон који уређује начин организовања и функционисања заједница на локалном нивоу је пре свега Закон о локалној самоуправи, који између осталог дотиче и питање учешћа грађана на локалном нивоу.

Са интензивирањем процеса европских интеграција, Србија је преузела значајан број правних аката с којима су на домаћем терену покренути бројни реформски друштвени процеси. Што се тиче процеса учешћа грађана од посебног је значаја то што је Сpбија априла 2003. године приступила Савету Европе, да би 2007. године ратификовала Европску повељу о локалној самоуправи. Тиме је постављен чврста основа јакој и стабилној локалној самоуправи у Србији.

Законом о локалној самоуправи дефинисано је да у Србији грађани могу да остваре своје право на учешће у раду локалне самоуправе на два начина, и то: непосредно (путем референдума, грађанских иницијатива и збора грађана) и посредно (преко својих слободно изабраних представника).

Најзначајнији и најопштији документи који формирају правни оквир учешћа грађана у Републици Србији су, дакле, између осталих, следећи правни акти:

- Устав Републике Србије

- Закон о локалној самоуправи

- Закон о референдуму и народној иницијативи

- Закон о удружењима

- Закон о слободном приступу информацијама од јавног значаја

- Појединачни статути градова и општина

Наравно, треба имати у виду да пракса учешћа грађана у јединицама локалне самоуправе (општинама и градовима) у Србији, укључује и низ појединачних ad hoc активности које нису посебно регулисане општим актима, него су резултат појединачних иницијатива и конкретних активности везаних за функционисање 
локалних самоуправа. У том смислу и овакве активности током времена постају део добре праксе и добрих обичаја, који формирају општи амбијент у коме се одвија пракса учешћа грађана.

Коначно, потребно је такође рећи да само формирање правног оквира за учешће грађана у процесу одлучивања о питањима од значаја за живот заједнице, не значи да је у Србији пракса о којој говоримо достигла пуни замах и да се може рећи да је њен достигнути ниво у складу са очекивањима и посебно са праксама из развијених европских земаља које нам служе као узор. Један од разлога, али и потврде ове чињенице јесте да у Србији још увек не постоји јасна стратегија на националном нивоу која би дала даље смернице, дефинисала улоге централних и националних власти, те олакшала развој непосредног учешћа грађана. Овоме треба додати и још увек релативно низак ниво свести и знања грађана о правима и начинима укључивања у функционисање њихових локалних самоуправа, који се огледају у њиховом недовољном познавању могућности и шанси које механизми учешћа грађана пружају за њихово активно и продуктивно укључивање у живот локалне самоуправе, као и њихових одговорности и обавеза у овом домену.

\section{3. НИВОИ УЧЕШЋА ГРАЋАНА У ДОНОШЕЫУ ОДЛУКА НА ЛОКАЛНОМ НИВОУ}

У зависности од облика и степена утицаја грађана на процесе доношење одлука у јавном сектору, можемо разликовати више нивоа њихове партиципације. Они се крећу од почетног нивоа који подразумева информисање грађана о питањима јавних политика, који по природи ствари уједно има и карактер едукације, иде даље преко прикупљана информација и упознавања са мишљењима и ставовима грађана; затим преко комуникације власти са грађанима која подразумева повратне везе (непосредни дијалог), до партнерског односа у коме грађани заиста партиципирају у процесу доношења одлука. 


\section{Слика 4.1: Нивои учешћа грађана на локалном нивоу}

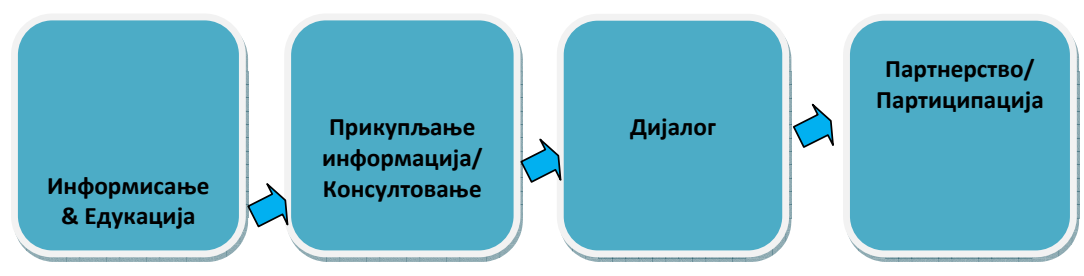

Као што се може видети у приказу, сваки од ових нивоа подразумева различит циљ учешћа грађана, различиту поруку коју представници власти шаљу грађанима у овом процесу и различите врсте, нивое и интензитет утицаја грађана на процес одлучивања у јавном сектору.

\section{3. ИНФОРМИСАЬЕ И ЕДУКАЦИЈА ГРАЋАНА}

Приступ информацијама је основа за све наредне кораке укључивања грађана у процес политичког одлучивања. Ово је релативно низак ниво учествовања грађана, који се обично састоји од једносмерног добијања информација од органа власти. Грађани су у овој фази само примаоци информација и не постоји интеракција између њих и органа власти. Међутим, пошто даљи ниво учешћа није могућ без прецизне и благовремене информације, овај први ниво је неопходан предуслов за све остале кораке у процесу доношења одлука.

Информисање грађана представља једносмерну комуникацију која не подразумева пружање повратних информација. Сврха тих активности је да пруже правовремене, прецизне и истините информације грађанима како би боље разумели дато питање, различите могућности, шансе и евентуална решења. Истовремено, доступност информација повећава могућност едукације грађана у вези с датим питањем, што подразумева још дубље разумевање проблема, разграничавање правих и истинитих информација од претпоставки, предрасуда, гласина итд. Ове две функције (информисање и едуковање јавности) повезане су и преплетене с активностима које у већини случајева немају само једну функцију, већ у себи обједињују обе. 


\section{4. КОНСУЛТАЦИЈЕ СА ГРАЋАНИМа}

Ова фаза партиципативног процеса представља прелазак из једносмерне на двосмерну, мада и даље релативно ограничену комуникацију тако што се грађанима и заинтересованим странама омогућава да дају свој допринос у виду повратних информација, мишљења и ставова о датом питању. Циљ ове фазе је да окупи заинтересоване стране, подстакне их на заједничку акцију, размену мишљења и ставова и директно и активно учешће у процесима од значаја за заједницу.

Двосмерна комуникација са локалном самоуправом омогућава грађанима да се активно укључе у живот заједнице. Одговорност за укључивање грађана подједнако је и на локалној самоуправи и на самим грађанима. Наиме, локална самоуправа се мора потрудити да на неки од расположивих начина, најпре информише и едукује грађане, а потом да креира и успостави разне механизме за њихово укључивање у живот локалне заједнице.

Позитивни ефекти ове фазе процеса учешћа грађана су бројни и они могу да, између осталог, обухвате следеће:

- обезбеђење заједничког разматрања евентуалних конфликата између заинтересованих страна и успостављања већег степена узајамног разумевања, што само по себи омогућава и подстиче међусобну сарадњу;

- јачање поверења грађана у локалну самоуправу због саме чињенице да су упознати с тим да је одлука донесена на партиципативан начин, у отвореном и поштеном процесу;

- подстицање разноликости мишљења и ставова бројних субјеката унутар заједнице и искоришћење ових разноликости за налажење креативних решења за добробит шире заједнице.

\section{5. ДИЈАЛОГ СА ГРАЂАНИМА}

Дијалог као форма укључивања грађана у управљање локалним самоуправама подразумева проширивање двосмерне комуникације изграђена на узајамним интересима и потенцијално заједничким циљевима локалних самоуправа и грађана, са циљем обезбеђења редовних размена ставова. Он се креће у распону од 
отворених јавних расправа до посебно организованих састанака између грађана и државних институција.

\section{6. ПАРТНЕРСТВО СА ГРАЂАНИМА}

Партнерство подразумева заједничку одговорност грађана и локалних самоуправа у свим областима и у свим фазама у процесима доношења одлука везаним за живот локалних заједница, од одређивања програма рада до израде нацрта и спровођења конкретних политика. Као такав он представља највиши облик непосредног учествовања грађана у животу локалних заједница.

Један од специфичних начина непосредног укључивања грађана у функционисању локалних самоуправа у форми партнерства јесте и активност невладиних организација (НBO). У овом контексту НВО и државне институције остварују тесну сарадњу, при чему НВО остају независне и имају право да спроводе кампање и да делују без обзира на партнерску ситуацију. Партнерство може да обухвати активности као што је делегирање одређених задатака некој НВО, на пример пружање услуга, стварање партиципативних форума и оснивање тела која доносе заједничке одлуке, укључујући и оне које се односе на расподелу ресурса.

\section{7. ИЗВЕШТАВАЊЕ ГРАЂАНА}

Извештавање се може третирати као посебна фаза у процесу укључивања грађана у одлучивање на локалном нивоу, али уједно и као специфични део сваке од претходно наведене фазе. Она у сваком случају означава окончање покренутог и реализованог циклуса учешћа грађана, али уједно представља и увод у наредни циклус партиципативних процеса који се циклично понављају везано за питања на које се односе (нпр. за буџетски процес, стратешко планирање итд.) у локалној заједници. Циљ извештавања о резултатима и доприносима грађана јесте да сумира резултате партиципативног процеса након донесене одлуке, представи одабрано решење и укаже на величину и значај доприноса грађана, доношењу дате одлуке. Ова компонента у процесу учешћа грађана је веома значајна јер грађанима указује на то колико су њихова мишљења и укупна активност имали утицај на процесе у локалној самоуправи. Наиме, информисани и едуковани грађани који су активно и директно учествовали у процесу одлучивања, желе 
и имају право да знају да ли је и у којој мери њихов допринос прихваћен. У супротном, ако остану ускраћени за ову информацију, могу стећи утисак да је њихово учешће било само формално и да локална самоуправа заправо није имала намеру да искористи њихов допринос.

\section{4. ИНСТРУМЕНТИ УЧЕШЋА ГРАЋАНА НА ЛОКАЛНОМ НИВОУ}

За сваки од наведених облика учешћа грађана, на располагању стоје бројне технике и методе чија је ефикасност вишеструко проверена и потврђена у пракси, како локалних самоуправа у развијеним земљама, тако и оних мање развијених. У наставку су без посебних објашњења о њиховим садржајима и карактеристикама, наведене неки од најважнијих.

Инструменти информисања и едукације грађана - Локалним самоуправама на располагању стоје бројни, врло разноврсни инструменти за информисање грађана. Неки од ефикасних и врло често коришћених инструмената за ову намену су, између осталих, следећи:

- Центар за информисање грађана (ЦИГ)

- Медији (штампани и електронски)

- Интернет

Инструменти консултовања (прикупљања информација) од грађана - Неки од ефикасних и врло често коришћених инструмената за ову намену су, између осталих, следећи:

- Формални разговори (интервјуи) са грађанима

- "Браинсторминг"

- „Технике номиналних група“ (ТНГ)

- Анкете /Упитници

- Фокус групе

Инструменти дијалога са грађанима - Неки од најзначајнијих инструмената учешћа грађана које локалним самоуправама стоје на располагању када желе да укључе своје грађане у дијалог и да са њима успоставе развијене партнерске односе су, између осталих, следећи:

- Јавне расправе, јавни састанци и дебате, округли столови и панел дискусије

- Саветодавне и радне групе грађана 


\section{5. ЕМПИРИЈСКО ИСТРАЖИВАҢЕ ПРАКСЕ УЧЕШЋЕ ГРАЋАНА У БУЏЕТСКОМ ПРОЦЕСУ У ГРАДОВИМА И ОПШТИНАМА У СРБИЈИ}

У овом поглављу изложени су резултати емпиријског истраживања праксе учешћа грађана у општинама и градовима у Србији реализованог у првој половини 2013. године. Структура истраживања је конципирана на основама горе изложених облика и инструмената који стоје на располагању грађанима као проверених форми добре праксе њиховог учешћа у локалним самоуправама и то пре свега у буџетском процесу.

\section{1. Основне методолошке претпоставке}

Истраживање је реализовано кроз посебно осмишљену и спроведену анкету за чије потребе је развијен посебан упитник. Упитник је дефинисан тако да укључи концепте и приступе учешћа грађана који су у претходним поглављима описани као примери добре праксе, са циљем да се утврди у којој мери су они прихваћени и колико су „заживели“ у пракси у општинама и градовима у Србији.

Питања у упитнику су груписана полазећи од три описана нивоа партиципације грађана у власти на локалном нивоу. Представницима локалне самоуправе су постављена питања којима је покушано да се утврди да ли, и у којој мери, се њихови грађани укључују у процес припреме (планирања), усвајања и извршења локалних буџета, конкретно да ли они своје грађане укључују у овој процес кроз:

(i) њихово информисање о буџетском процесу,

(ii) прикупљање информација од грађана са циљем да се њихове потребе и преференције у што већој мери уваже у процесу планирања, а касније и током извршења локалног буџета и

(iii)успостављање дијалога са грађанима и њихово укључивање у процесе одлучивања везаних за планирање, извршење и контролу буџетског процеса. 
Ови облици и димензије партиципације грађана на локалном нивоу анализирани су по појединим фазама буџетског процеса, и то по три следеће основне фазе буџетског процеса:

- Планирање и припрема буџета,

- Извршење буџета и коначно,

- Контрола реализације буџета.

Неке од основних карактеристика истраживања, тј. реализоване анкете, могу се сажети у следећем:

- Упитник је послат свим општинама и градовима (њих 145) у Србији, тј. свим јединицама локалне самоуправе (њих 167) које укључују, како самосталне, тако и градске општине које су у саставу појединих градова.

- Упитник је послат електронском поштом на званичне мејл адресе ЈЛС и посебно на мејл адресе њихових одељења за буџете и финансије; након тога су у неколико наврата телефоном контактирани руководиоци ових одељења.

- У периоду од око 10-так недеља (од фебруара до априла 2013. године) добијено је укупно 50 одговора, од чега 48 од општина и градова (самосталних јединица локалних самоуправа) и две градске општине које су у саставу града Београда (Чукарица и Лазаревац).

Преглед општина укључених у истраживање

\begin{tabular}{|c|c|c|c|}
\hline $\mathrm{Ho}$ & $\begin{array}{l}\text { JЕДИНИЦЕ } \\
\text { ЛОКАЛНИХ } \\
\text { САМОУПРАВА }\end{array}$ & Ho & $\begin{array}{l}\text { ЈЕДИНИЦЕ } \\
\text { ЛОКАЛНИХ } \\
\text { САМОУПРАВА }\end{array}$ \\
\hline 1 & Алексинаш & 27 & Медвеђа \\
\hline 2 & Апатин & 28 & Неготин \\
\hline 3 & Ариље & 29 & Нови Бечеј \\
\hline 4 & Бачка Топола & 30 & Нови Кнежевац \\
\hline 5 & Баточина & 31 & Параћин \\
\hline 6 & Беочин & 32 & Пећинши \\
\hline 7 & Босилеград & 33 & Пирот \\
\hline 8 & Брус & 34 & Прокупље \\
\hline 9 & Бујановац & 35 & Рашка \\
\hline 10 & Ћуприја & 36 & Рума \\
\hline 11 & Чајетина & 37 & Сокобања \\
\hline 12 & Чока & 38 & Сомбор \\
\hline 13 & Голубаш & 39 & Сремска Митровища \\
\hline
\end{tabular}




\begin{tabular}{|c|c|c|c|}
\hline Ho & $\begin{array}{l}\text { JЕДИНИЦЕ } \\
\text { ЛОКАЛНИХ } \\
\text { САМОУПРАВА }\end{array}$ & $\mathrm{Ho}$ & $\begin{array}{l}\text { JЕДИНИЦЕ } \\
\text { ЛОКАЛНИХ } \\
\text { САМОУПРАВА }\end{array}$ \\
\hline 14 & Горњи Милановаш & 40 & Стара Пазова \\
\hline 15 & Ивањица & 41 & Суботиша \\
\hline 16 & Јагодина & 42 & Шид \\
\hline 17 & Кањижа & 43 & Топола \\
\hline 18 & Ковин & 44 & Тутин \\
\hline 19 & Крагујеващ & 45 & Врњачка Бања \\
\hline 20 & Краљево & 46 & Вршаш \\
\hline 21 & Крупањ & 47 & Зајечар \\
\hline 22 & Куршумлија & 48 & Жагубиша \\
\hline 23 & Лапово & 49 & Житорађа \\
\hline 24 & Љиг & 50 & Чукарица \\
\hline 25 & Љубовија & 51 & Лазаревац \\
\hline 26 & Мајданпек & & \\
\hline
\end{tabular}

Истраживањем је, дакле, било обухваћено $33.8 \%$ свих градова и општина у Србији (у прегледу је приказана листа градова и општина који су попунили упитнике).То се може сматрати репрезентативним обухватом на основу којег је могуће доносити кредибилне закључке о пракси коришћења инструмената учешћа грађана у јединицама локалних самоуправа у Србији.

\section{2. РЕЗУЛТАТИ АНКЕТЕ}

Анкета чије су карактеристике презентоване у горњим редовима, имала је за циљ пре свега да идентификује облике пракси учешћа грађана које ЈЛС у Србији користе у различитим фазама буџетског процеса. При томе амбиција истраживања није била да се дође до информација или показатеља о ефективности коришћења ових инструмената учешћа грађана. Оваква врста информација би захтевала посебна додатна истраживања која би пре свега била базирана на методи појединачних студија случаја.

Резултати анкете у целини указују да општине и градови у Србији у својој буџетској пракси користе разноврсне инструменте учешћа грађана. Оно што се може издвојити као специфичност у начину на који се они користе јесте да се облици и интензитет 
њиховог коришћења разликују у зависности од фаза буџетског процеса. Анкета је указала на следеће специфичности коришћења инструмената учешћа грађана у ЈЛС у Србији:

- Укључивање грађана у буџетски процес се врши на релативно најразноврснији и најинтензивнији начин у првој фази буџетског процеса, а то је фаза планирања:

о Тако у овој фази преко 90\% ЈЛС користи електронске медије да информише грађане о планирању буџета, а око $67 \%$ користи штампане медије;

о Утврђивање/прикупљање мишљења и преференција грађана као специфичне форме учешћа грађана, нешто се мање користи у овој фази: око $30 \%$ ЈЛС користи инструменте евидентирања мишљења, а нешто више од $20 \%$ организује у ову сврху посебна истраживања;

о Коначно, значајан број ЈЛС у оквиру локалног буџетског процеса користи и инструменте дијалога са својим грађанима у оквиру којих остварују двострану комуникацију. Врло распрострањен и често коришћен је метод комуницирања са грађанима посредством месних заједница: преко 60\% анкетираних ЈЛС имају ову праксу, a око 50\% такође користи и укључивање грађана у различита радна тела и организацију различитих врста јавних састанака са грађанима (јавних расправа, дебата и сл.).

- Истраживање је показало да локалне самоуправе такође у значајној мери укључују грађане у фази извршења буџета. Ипак интензитет коришћења ових инструмената је нешто нижи односу на фазу планирања:

о Око 75\% локалних самоуправа информишу грађане о извршењу буџета коришћењем електронских медија, а око 57\% користи штампане медије;

о Информације се од грађана у овој фази буџетирања прикупљају у мањој мери: око 8\% анкетираних ЈЛС је евидентирало њихово мишљење, а само око $2 \%$ је организовало посебна истраживања;

о Преко 35\% ЈЛС користи месне заједнице и посебно формирана тела као инструменте посредством којих се остварује дијалог са грађанима.

- Коначно у последњој фази буџетског процеса у којој се врши његова контрола, инструменти учешћа грађана се користе у најмањој мери: 
о у овој фази ЈЛС информишу грађане путем електронских медија у нешто преко $30 \%$ случајева, а у нешто преко $15 \%$ случајева користе штампане медије;

о од грађана се у начелу не прикупљају информације везано за контролу буџетског процеса;

о у месним заједницама, као и у посебно формираним групама грађана, један број ЈЛС организује дијалог са својим грађанима везано за контролу буџетског процеса (око $12 \%$, односно $2 \%$, респективно).

Јединице локалних самоуправа у Србији, дакле, релативно интензивно користе инструменте учешћа грађана који се могу означити као добре праксе у фази планирања својих буџета. Ово указује на чињеницу да локални званичници у Србији заиста покушавају да у процесу припреме буџета укључе грађане. То пре свега чине тако што их информишу, док се у знатно мањој мери труде да прикупе информације о потребама и жељама грађана. Занимљиво је, међутим, да ЈЛС у релативно значајној мери користе форме учешћа грађана који се сматрају напредним чак и у развијеним земљама, а то је дијалог са грађанима и њихово укључивање у процес одлучивања. Кључну улогу у овоме, по свему судећи, имају месне заједнице, које иначе представљају значајно, могло би се рећи већ историјско искуство и тековину локалних самоуправа у Србији. Наиме, управо су месне заједнице, најважнија тела посредством којих се остварују дијалози између локалних званичника и грађана.

У фази извршења буџета, ЈЛС у Србији, такође користе неке од добрих пракси учешћа грађана, али то ипак чине значајно мање интензивно него у фази планирања. У овој фази учешће грађана се у највећој мери исцрпљује у информисању грађана, мада и у овој фази месне заједнице имају одређене улоге у успостављању дијалога локалних званичника и грађана.

У фази контроле буџетског процеса у којој се дефинитивно утврђује у којој је мери локални буџет извршен у складу са планом, локалне самоуправе у Србији користе у најмањој мери инструменте учешћа грађана. Известан мањи проценат ЈЛС информише грађане о овој фази; мишљења грађана се не истражују, а врло мали број остварује у овој фази дијалог са грађанима и то опет посредством месних заједница. 


\section{ЛИТЕРАТУРА}

- $\quad$ Creighton, J.L. The public participation handbook: making better decision through citizen involvement, Jossey-Bass, San Francisco, 2005.

- Gastil, J., Levine, P. (ed.). The deliberative democracy handbook: strategies for effective civic engagement in the twenty first century, JosseyBass, San Francisco, 2005.

- Gramberger, M. The Citizens as Partners - OECD Handbook on Information, Consultation and Public Participation In Policy-Making, OECD, Paris, 2001.

- $\quad$ Shaping the future together. The Public Participation Manual, Austrian Society for Environment and Technology, Vienna, 2007.

- Mežnarič, I. Handbook on Planning, Managing and Evaluating Public Participation Processes, Ministry of Public administration, Ljubljana, 2008.

- $\quad$ Participatory and Deliberative Methods Toolkit, How to Connect with Citizens, A Practitioner's Manual, King Baudouin Foundation and the Flemish Institute for Science and Technology Assessment, 2005

- $\quad$ Приручник за примјену кодекса добре праксе за учешће грађана у прочесу доношења одлука, Центар за развој невладиних организација (ЦРНВО), Подгорица, март 2012.

- Административни правни и институционални оквир за врщење локалне управе, Центар за демократску културу, Београд, 2003.

- Public Participation in Europe an International Perspective, European Institute for Public Participation (EIPP), 2009 http://www.participationinstitute.org/wp-ontent/uploads/2009/06/pp_in_e_report_03_06.pdf

- $\quad$ Практични водич за учешће градјана, УСАИД програм Програм за реформу локалне самоуправе у Србији, Београд, 2005.

\section{Zvonko Brnjas, Bozo Draskovic}

\section{CITIZENS AND BUDGET PROCESS AT THE LOCAL LEVEL}

\section{Resume}

The Citizen Participation (in the broad sense: participation of the general public) is a very important aspect of the functioning of the socio-economic systems in transitional countries. This question is important both from the standpoint of democratic development, as well as efficient and effective economic system, especially the part which rela- 
tes to the public sector of the system (public or government sector in the broadest sense). The participation of the citizens is the process by which problems, needs and desires of citizens are implanted in the decision-making process of local government. It involves two-way communication between citizens and local governments which common goal is to make better decisions that have public support. At the local level, public participation can influence decisions in different areas in the field of adoption of local public policies and legislation, the preparation and adoption of local development plans and programs, as well as in defining and implementing specific projects at the local level.

In the paper the particulare emphasis has been put on the question of inclusion of the citizens in the budget process at the local level in the Local Government Units (cities and municipalities) in Serbia. Depending on the type and level of influence in the decision making process in the public sector, we can distinguish several levels of their participation. They range from the basic level, which involves informing the public about issues of public administration (this form by definition also has the character of education); extends over the collecting information and learning about the opinions and attitudes of citizens; then through communication between citizens and government which includes feedback (direct dialogue), up to the development of partnership of these two parties in which citizens participate directly in the decision-making process.

Keywords: Local Government, Citizen Participation, Budget Process, Transparency of Public Functions, Legal Framework of Citizen Participation.

Овај рад је примљен 12. новембра 2014. године а прихваћен за штампу на састанку Редакције 26. новембра 2014. године. 